\title{
BIBLICAL AND OTHER QUOTATIONS
}

Biblical references are to the Latin Vulgate and the English Douai translation. These contain some books which appear only in the Apocrypha of most other English translations and some books have different names. Where references (notably in the numbering of the Psalms) or names of books differ in the Authorised Version, those from the latter are given in brackets. In translating Biblical quotations I have used both the Douai translation and the Authorised Version more or less interchangeably according to the needs of the context.

Exact quotations from the Bible are italicised; Biblical allusions are in normal type. For material from non-Biblical sources, I have used quotation marks to indicate those parts of the text known to have been lifted directly from another source. 
David Jones - 9781526112811

Downloaded from manchesterhive,com at $04 / 26 / 2023$ 07:35: $06 \mathrm{AM}$ 